\title{
United States - China Relations: Prospects during Xi - Biden Tenure
}

\author{
Srikanth Kondapalli \\ Jawaharlal Nehru University, New Delhi, India \\ $\bowtie$ profsrikanthkondapalli@gmail.com
}

\begin{abstract}
Bilateral relations between China and the United States have become strategic in nature with implications to the rest of the world. Both have been engaging and competing on a number of issues in the recent times. While both seek security and stability so as to pursue their respective national interests, they differ on the way they pursue these. While engagement has been the dominant theme in the previous administrations, since late Trump, bilateral relations exhibited tensions on a number of issues including what China considered to be its "core interests". China's agenda of "keeping a low profile" has been changed to "accomplish something" and it intends to "occupy the centre stage" in the long-term. The election of Joseph Biden as the President of the US coincided with the ongoing reassessments on the bilateral relations as well as coming to the fore of tensions on a number of fronts with China. The spread of COVID-19 pandemic, decline in global growth rates, disruptions in supply chains, and the growing uncertainty have only further exacerbated the US - China relations. Below is a review of the bilateral relations in the recent times by eliciting cooperative and competitive trends between China and the US. It is argued that the US - China relations are undergoing major shifts due to the tensions even as both are for ushering in strategic stability. China's perceptions at the leadership level, media and academic levels are outlined in brief to suggest that relations with the US are exhibiting tensions on a number of issues that pose challenges and opportunities for other countries.
\end{abstract}

Key words: United States - China relations, strategic stability, competition, cooperation, flux in relations

For citation: Kondapalli, S. (2021). United States - China Relations: Prospects during Xi - Biden Tenure. Vestnik RUDN. International Relations, 21(2), 279-287. https://doi.org/10.22363/2313-0660-2021-21-2-279-287

\section{Перспективы американо-китайских отношений в период правления Си Цзиньпина и Джо Байдена}

\author{
Ш. Кондапалли \\ Университет Джавахарлала Неру, Нью-Дели, Индия \\ 凹profsrikanthkondapalli@gmail.com
}

\begin{abstract}
Аннотация. Двусторонние отношения между Китаем и США приобрели стратегический характер с последствиями для остального мира. Оба государства в последнее время взаимодействуют и конкурируют друг с другом по ряду вопросов. Хотя и КНР, и США стремятся обеспечить свою безопасность и стабильность, что связано с их национальными интересами, они используют разные инструменты для достижения этой цели. В то время как американо-китайские отношения отличались преимущественно сотрудничеством при прошлых президентах США, во вторую половину президентства Д. Трампа двусторонние отношения характеризовались напряженностью по ряду вопросов, включая то, что Китай считал своими «коренными интересами». Внешнеполитическая повестка дня КНР, заключающаяся в том, чтобы «оставаться в тени»,
\end{abstract}

(C) Kondapalli S., 2021

This work is licensed under a Creative Commons Attribution 4.0 International License.

https://creativecommons.org/licenses/by/4.0/ 
была изменена на «делать что-то реальное», в рамках которой Пекин намерен «занять центральное место» в долгосрочной перспективе. Избрание Дж. Байдена президентом США совпало с продолжающейся переоценкой американо-китайских отношений, а также с выходом на первый план напряженности по ряду направлений с Китаем. Распространение пандемии COVID-19, снижение темпов роста мировой экономики, сбои в цепочках поставок и растущая неопределенность только усугубили отношения между США и Китаем. В статье приводится обзор двусторонних отношений за последние годы с выявлением тенденций как к сотрудничеству, так и к соперничеству между США и Китаем. Утверждается, что американо-китайские отношения претерпевают серьезные сдвиги из-за напряженности, хотя оба государства выступают за установление стратегической стабильности. Реферативно излагается восприятие Китая на уровне руководства, в СМИ и на академическом уровне. Автор делает вывод, что отношения с США демонстрируют напряженность по ряду вопросов, которые создают проблемы и возможности для других стран.

Ключевые слова: американо-китайские отношения, стратегическая стабильность, соперничество, сотрудничество, переменчивость в отношениях

Для цитирования: Kondapalli S. United States - China Relations: Prospects during Xi - Biden Tenure // Вестник Российского университета дружбы народов. Серия: Международные отношения. 2021. Т. 21. № 2. C. 279 -287. DOI: $10.22363 / 2313-0660-2021-21-2-279-287$

\section{Introduction}

China observed carefully the 2020 election campaign and outcome in the United States, although it was slow in responding to the electoral victory of Joseph Biden as the President. Nevertheless, at various levels, Beijing had articulated its responses and preparing to influence the new US Administration. The stakes for both are high with some pointing to a potential power transition but with the spread of the COVID-19 pandemic most countries including the US and China constrained in their outreach and economic well-being. The debilitating COVID-19 pandemic has sapped economic growth rates, international trade, supply chain mechanisms, technological disruptions, and the health condition of millions of people across the globe. An analysis of the China - US relations in this context is important given their extensive enmeshing into a whole gamut of things [Tao 2015; Sutter 2020; Fels 2016; Odgaard 2007; Yetiv, Oskarsson 2018; Allison 2017]. Below is a brief overview of the challenges that beset the bilateral relations between China and the US in the context of the recent ushering in of the Biden Administration in the US.

A number of issues confront the bilateral relations which in the last decade have become strategic in nature. These include trade deficits in favour of China [Qiu, Wei 2019; Chi, Qiao 2020], investments [Rosen, Hanemann 2014], the role of Huawei and ZTE telecommunication and other firms in the US market [Lysne 2018; Liu 2021], Tibet [Kubo 2019], Taiwan [Yang 2021], Xinjiang [Zuo 2021], Hong Kong [Boylan, McBeath, Wang 2021], South China Sea [Askari, Tahir 2020], Senkaku Islands [Oliveira 2021], Indo-Pacific [Gopal 2017], Quad [Ye 2020] and others. These were compounded by statements from both sides ${ }^{1}$.

President Xi Jinping's delayed congratulatory message to President-elect Biden came on November 25 with a message for cooperation and managing differences ${ }^{2}$. In contrast, in 2016 when Donald Trump was elected, Xi Jinping was one of the earlier leaders to greet the new President (after the Japanese, Mexican, German and other leaders). This time around, China was cautious to approach J. Biden on January 20 given the number of issues thrown open by the Trump Administration. Since 2013, when the

1 Xi Jinping's speech at the virtual Davos Agenda event // CGTN. January 26, 2021. URL: https://news.cgtn. com/news/2021-01-25/Full-text-Xi-Jinping-s-speech-atthe-virtual-Davos-Agenda-event-Xln4hwjO2Q/index.html (accessed: 29.01.2021); Dialogue with National Committee on U.S.-China Relations // Xinhua. February 2, 2021. URL: http://www.xinhuanet.com/english/2021-02/ 02/c_139715299.htm (accessed: 06.02.2021).

${ }^{2} \mathrm{Xi}$ and Biden are no strangers to each other. In fact, they spent quality time interacting with each other as Vice Presidents before. One anecdote is when $\mathrm{Xi}$ asked about the essence of the US, Biden replied to "possibilities". However, the context of the US-China relations changed substantially in the last few years as the bipartisan consensus in the US considered China as a challenge with the latter's policies of exhibiting assertiveness. 
Chinese side articulated the "new type of major power relations" at Sunny lands with President Obama, its operative phrase was "non-conflict, non-confrontational and win-win cooperation" [Lampton 2013]. President Obama also suggested to Group 2 with China to address the global and regional issues. However, as China's ambitions increased to nudge the US away from Asia $^{3}$, the Trump Administration's push back policies suggested to the emerging conflict between the two. Xi's offer of managing differences is to buy time and deflect the US from China. Finally, on February 11, 2021 both leaders spoke on phone ${ }^{4}$.

\section{Troubled Engagement Policies}

Last four decades of bilateral relations between China and the US are based on engagement policies initiated by Mao Zedong and President Nixon since the 1970s. Deng Xiaoping and President Carter further solidified the bilateral relations mainly in three areas, support to the strategic rise of China to counter the then Soviet Union, stability in bilateral relations and an understanding on Taiwan issue [Sargent 2014]. Both have in the four decades expanded economic and trade relations to become large trading partners. Bilateral trade thus increased from a mere 2.37 billion USSD in 1979 to a more than 599 billion USD in 2016 to over 500 billion USD last year, despite the COVID-19 disruptions ${ }^{5}$. However, trade deficit since the 1990s peaked in favour of China leading to sharp criticism from the US in the recent times on lack of market access and less investments, renminbi currency valuation, loss of jobs, intellectual property rights and other issues.

3 Stay on the Right Track and Keep Pace with the Times to Ensure the Right Direction for China - US Relations // Ministry of Foreign Affairs of the People's Republic of China. July 9, 2020. URL: https://www.fmprc. gov.cn/mfa_eng/wjb_663304/wjbz_663308/2461_663310/t 1796302.shtml (accessed: 06.02.2021).

${ }^{4} \mathrm{Xi}$ speaks with Biden on phone // Ministry of Foreign Affairs of the People's Republic of China. February 11, 2021. URL: https://www.fmprc.gov.cn/mfa_eng/zxxx_ 662805/t1853684.shtml (accessed: 18.02.2021).

5 Trade in Goods with China // United States Census Bureau. March 15, 2021. URL: https://www.census.gov/ foreign-trade/balance/c5700.html (accessed: 18.02.2021). See also: [Wang 2010].
The bilateral understanding in April 6-7, 2017 at Mar-a-Lago on a 100-day action plan to resolve trade differences and subsequently the January 2020 understanding have all proved to be contentious raising tariff wars between the two and spilling over other issues such as restrictions on Huawei, ZTE and other Chinese companies. The engagement policies adopted since the 1970s are also based on an understanding on a number of issues such as countering proliferation of weapons of mass destruction, coordination on regional security issues such as Afghanistan initially and then on North Korea, Iran and others. It also took the form of cooperation on counterterrorism in the post-9/11 times as well as on energy security.

However, the failure of the January 2020 agreement on tariffs has spilled over into many other issues mentioned above. In a speech by the then US Secretary of State Mike Pompeo at President Richard Nixon Presidential Library the basic tenets of the bilateral relations of over four decades were questioned. Pompeo stated that the engagement policies pursued by the US since 1971 have failed to deliver and alluded to the emergence of bi-partisan consensus in the US on China as a competitor. This rattled Beijing of a systematic "decoupling" process and an emerging new Cold War between the two. The spread of COVID-19 from Wuhan to the rest of the world, including to the US (with an estimated half a million travellers from Wuhan before the lockdown on January $23,2020^{6}$ ) further led to tensions with President Trump calling it "Chinese virus", while China retorting it as "political virus"?. Trump / Pompeo's criticisms were met by China's "wolf warrior" diplomacy ${ }^{8}$.

6 430,000 People Have Traveled From China to U.S. Since Coronavirus Surfaced // The New York Times. April 5, 2020. URL: https://www.nytimes.com/2020/ 04/04/us/coronavirus-china-travel-restrictions.html (accessed: 18.02.2021).

7 Transcript of State Councilor and Foreign Minister Wang Yi's Exclusive Interview with Reuters // Ministry of Foreign Affairs of the People's Republic of China. February 15, 2020. URL: https://www.fmprc.gov.cn/ mfa_eng/wjb_663304/wjbz_663308/2461_663310/t17452 64.shtml (accessed: 06.02.2021).

8 Wang Q. Over 70\% respondents believe China's global image has improved, 'wolf warrior diplomacy' a necessary gesture: GT poll // Global Times. December 25, 


\section{Flux in Relations}

For early more than a year there has been a flux in the bilateral relations between China and the US. The Biden Administration's signalling on following some of the previous policies indicated to Beijing that it is going to be long drawn-out battle. Biden had mentioned his preferences for reviving alliances, joined the climate change, human rights and World Health Organisation and other institutions. While foreign minister Wang Yi dismissed Pompeo's statement as a reflection of "Cold War mentality" but agreed that the situation is "most complicated". Wang reminded the US of over 70,000 American companies' 700 billion USD investments in China that are still making profits despite COVID-19. They also generate 2.6 million jobs in the US. This is intended to woo the business lobbies in the US and make them exert pressure on Biden ${ }^{10}$. Wang nevertheless said bilateral relations are facing "gravest challenge". Wang suggested "three lists" to be observed, viz., dialogue, cooperation and managing differences properly ${ }^{11}$.

Overall, China's bottom line is how it can consolidate its position as 2nd largest economy

2020. URL: https://www.globaltimes.cn/content/ 1211003.shtml (accessed: 18.02.2021).

${ }^{9}$ Interview on Current China-US Relations Given by State Councilor and Foreign Minister Wang Yi to Xinhua News Agency" // Ministry of Foreign Affairs of the People's Republic of China. August 6, 2020. URL: https://www.fmprc.gov.cn/mfa_eng/wjb_663304/wjbz_663 308/2461_663310/t1804328.shtml (accessed: 18.02.2021).

10 See: Interview on Current China - US Relations Given by State Councilor and Foreign Minister Wang Yi to Xinhua News Agency // Permanent Mission of the People's Republic of China to the UN. August 6, 2020. URL: $\quad$ http://www.china-un.ch/eng/ryrbt/t1804455.htm (accessed: 12.08.2020); Vision and Conviction Will Take China - US Relations Forward // Ministry of Foreign Affairs of the People's Republic of China. September 25, 2019. URL: https://www.fmprc.gov.cn/mfa_eng/wjb_ 663304/wjbz_663308/2461_663310/t1701595.shtml (accessed: 12.08.2020).

11 Reorient and Steer Clear of Disruptions - For a Smooth Sailing of China - U.S. Relations // Ministry of Foreign Affairs of the People's Republic of China. December 19, 2020. URL: https://www.fmprc.gov.cn/ mfa_eng/wjb_663304/wjbz_663308/2461_663310/t18413 80.shtml (accessed: 23.12.2020). (and the largest by 2028) ${ }^{12}$. This could further elevate China's stakes and the inability of the US to penalise on any count. China's minimalist demands on the Biden Administration are likely to be on arms sales and civilian / military officials visit to Taiwan, Tibet travel and the Dalai Lama's succession issue, freedom of navigation in the South China Sea, incarceration of Uighurs in Xinjiang and Hong Kong arrests. China's maximalist positions are likely to provide much friction with the US specifically on China becoming a global and regional power, leader in 5G and artificial intelligence, with its Belt and Road Initiative firmly ensconced, its "community of common destiny" gaining friends and allies in the world, with China poised to "occupying the centre stage" as the 19th Communist Party Congress decided in 2017 [Swaine 2018].

In relation to the new US Administration, China could propose a few areas of cooperation, realising the potential benefits of continuing to associate with the US. China may send a highlevel business delegation to the US or conduct an online summit with the new leader given the COVID-19 distancing norms. It could approach the US with cooperation stance on climate change, multilateralism, WTO dispute mechanism and other issues closer to the US Democrats. China could even propose vaccine development to profit from the pandemic, although the US (and Russia) has refused to join the UN-led Covax initiative. Counterterrorism could be another subject of cooperation between the two, specifically as the situation in Afghanistan is reaching a point of conciliation.

China's negative list for the Biden Administration is on its "core issues" such as Taiwan, Tibet, South China Sea and Xinjiang but also on tariffs, abrogation of the intermediaterange nuclear forces (INF) treaty and nudging China to commit for strategic arms reduction measures and also of the ban on Chinese Communist Party members that the outgoing

12 World Economic League Table 2021 // Centre for Economics and Business Research. December 26, 2020. URL: https:/cebr.com/wp-content/uploads/2021/02/WELT2021-final-15.01.pdf (accessed: 10.01.2021). 
Trump Administration has placed. The latter led to the intensification of ideological struggle between the two countries but also, at an existential level, to the growing influential cadres' sons and daughters visits to the US.

In this context, China is likely to make big announcement on investments, tariffs, buying soya beans or beef and other products from the US but in practice does not implement the same but seek further concessions from the US. China is also likely to nudge North Korea and Iran to step up their confrontation with the US, as a useful distraction as ancient strategist Sun $\mathrm{Zi}$ recommended. With its recently launched 14th Five Year Plan focus on "dual circulation" strategy of balancing exports and imports and enhancing domestic consumption, in addition to the Made in China 2025 campaign, China also wants to distance from the US and other countries.

For the two to make the tango, China's bottom list has to match with the US list. The US business lobbies have been complaining about the protectionist trends in China despite its leaders' statements at Davos on leading globalisation. For instance, on market access, the US wants 100 per cent wholly owned companies in China, American credit card entry, licenses to the US companies and sale of biotech seeds ${ }^{13}$. The US trade deficits with China - a major subject in all election campaigns in the US - is ballooning despite the January 2020 deal, which has not been implemented. The trade deficit in favour of China amounted to a whopping 412 billion USD in 2018 that continued into $2020^{14}$.

Also, in a speech in April 2020, President Xi Jinping observed that China will "develop powerful retaliation and deterrence capabilities against supply cut-offs by foreign parties"15.

13 Kondapalli S. China Sees Strategic Opportunities with Biden // Chintan. India Foundation Blogs. January 7, 2021. URL: https:/chintan.indiafoundation.in/articles/ china-sees-strategic-opportunities-with-biden-2/ (accessed: 10.02.2021).

14 US Trade Deficit with China and Why It's So High // The Balance. January 21, 2021. URL: https://www.thebalance.com/u-s-china-trade-deficit-causeseffects-and-solutions-3306277 (accessed: 10.02.2021).

15 Tang F. China puts supply chain security at forefront to avoid being 'strangled' by sanctions, analysts say //
According to a US Department of Defense report, China is intending to use force to secure supply chain management in Asian region ${ }^{16}$. Of the three major global production chains in the US, Europe and Asia, the latter has grown substantially thanks to the rise of Japan, China, India, Vietnam, Indonesia and other countries but China wants to dominate. With COVID-19 disruptions and the recent campaign of "sustainable supply chains" by the Indo-Pacific countries, China is feeling that it is losing the initiative and hence wants to resolve the issue by the use of force in its favour.

Another red line of the US is the penchant of the Chinese businesses to influence the decision-making bodies in the US through mergers and acquisitions or even hostile takeovers, besides dangling the carrot to the US chamber of commerce on benefits in China market. In the 1990s, the US Congress restricted China's offshore oil company CNOOC from taking over Unocal ${ }^{17}$. Recently, Alibaba's Ant Group - which is in itself in trouble in China intended to takeover MoneyGram International ${ }^{18}$.

There are also other restrictions that the outgoing Administration had undertaken that may come in handy for the new Administration. In any case, the Republican-dominated legislatures could pose challenges to the new dispensation if it alters the recent measures which include over 1,000 China's militaryconnected researchers fleeing from the US; over 1,000 Chinese students who are under watch for

US - China Relations. November 10, 2020. URL: https://www.scmp.com/economy/china-economy/article/ 3109082/china-sacrificing-economic-growth-selfsufficiency-strategy (accessed: 10.02.2021).

16 The China Military Power Report 2020 // Office of the Secretary of Defense. 2020. URL: https://media.defense.gov/2020/Sep/01/2002488689/-1/-1/ 1/2020-DOD-CHINA-MILITARY-POWER-REPORTFINAL.PDF (accessed: 10.02.2021).

17 The CNOOC Case // Peterson Institute for International Economics. August 2006. URL: https://piie.com/publications/chapters_preview/3942/05iie3 942.pdf (accessed: 23.02.2021).

18 The US Government blocks MoneyGram's \$1.2B sale to Alibaba's Ant Financial // TechCrunch. January 3, 2018. URL: https://techcrunch.com/2018/01/02/ moneygram-ant-financial-alibaba-deal-collapses/ (accessed: 23.02.2021). 
espionage or other activities; shutting down of Houston Consulate of China, closure of several Confucius Institutes for their interference in the American campuses and others [Yang 2021].

The "bipartisan consensus" as reflected in the December 2017 US National Security Strategy report or the recent State Department report on "The Elements of the China Challenge" has signalled to the competitive element with China" ${ }^{19}$. Also, the anonymous "Longer Telegram" is making waves in the US invoking George Kennan's "long telegram" of 1946 that ushered in the Cold War era, an anonymous author had suggested that the US should treat China as the most significant challenge to its position [Anonymous 2021]. These would be hard for the new Administration to jettison. Of course, there is a lurking feeling in China that Biden could be more systematic and coordinated in his response to China's rise than compared to Trump Administration.

\section{Media and Policy Circles in China}

China's media, academic and policy circles are close to the party-state and most of them are Communist Party members. Hence, while some variation or dilution may occur in their views, their opinions are closely reflective of the partystate perspectives. Some think tanks like the China Institutes of Contemporary International Relations have 90 per cent of their research channelised to the government, while 10 per cent of such research findings make it to the public domain ${ }^{20}$. The Politburo of the Communist Party also had entertained the views of experts since $\mathrm{Hu}$ Jintao's time and special briefing sessions are conducted with them.

All China media is controlled by the partystate and they reflect to the priorities of the "party line". A survey conducted by Global

19 The Elements of the China Challenge // Office of the Secretary of State. December 2020. URL: https://www.state.gov/wp-content/uploads/2020/11/2002832-Elements-of-China-Challenge-508.pdf (accessed: 23.02.2021).

20 Abb P. China's Foreign Policy Think Tanks: Changing Roles and Structural Conditions // GIGA Working Papers. January 2013. No. 213. URL: https://www.files.ethz.ch/isn/159102/wp213_abb.pdf (accessed: 23.02.2021).
Times in December 11 to 17,2020 with about 2,000 respondents from 16 cities - 47 per cent said the US has a major impact on China, down from 82 per cent in 2019. 31 per cent believed Biden may ease tensions with China, while 28 per cent were pessimistic, and nearly 40 per cent unclear $^{21}$.

Leading American specialists in China as well have been less optimistic about the Biden Administration $^{22}$. However, much like the post9/11 counter-terrorism global consensus that distracted the then Bush Administration from pursuing "strategic competition" with China in 2001 to launching disastrous campaigns in Afghanistan, Iraq and other countries, the current COVID-19 and domestic issues could distract the Biden Administration as well — with the field wide open for China to realise its "strategic opportunities" once again. Below is a brief survey of the American specialists' views in China. A majority of them suggest to the impending competition with the US, although many of them discount the "Thucydides' trap" of conflict between an established power and an emerging power.

In the economic field, think-tankers like Zhang Xiaoqiang of the China Centre for International Economic Exchanges (CCIEE) suggest to China advocating globalisation and accrue benefits from free trade and investment climate and exploration of new markets, even as China needs to intensify its domestic consumption $^{23}$. Zhang also suggests to the

${ }^{21}$ Chinese rational on China - US ties: GT poll // Global Times. December 26, 2020. URL: https://www.globaltimes.cn/page/202012/1211038.shtml (accessed: 23.02.2021).

22 Chinese scholars expect Biden's victory to ease US-China tensions // Taiwan News. November 9, 2020. URL: https://www.taiwannews.com.tw/en/news/4048974 (accessed: 12.12.2020); Compendium of Recommendations on China Policy for the Biden Administration // The Wilson Center. January 8, 2021. URL: https://www.wilsoncenter.org/article/compendiumrecommendations-china-policy-biden-administration (accessed: 14.02.2021).

${ }^{23}$ CCIEE Executive Vice Chairman Zhang Xiaoqiang Meets with Matthew Murray, Economic Counselor of the US Embassy in Beijing // China Center for International Economic Exchanges. August 19, 2019. URL: http://english.cciee.org.cn/Detail.aspx?newsId=16998\&TId 
benefits of Regional Comprehensive Economic Partnership (RCEP) and the necessity to sign more FTAs for the rise of China. Chen Wenling argued that as labour wages are increasing in China, it is necessary to shift the manufacturing sector to the third line regions of China and into the Belt and Road Initiative regions or even shifting to some countries. She insists that while transfer of industrial capacities to the neighbourhood is made, China needs to insist on market hold and integration ${ }^{24}$.

At the political level, Ambassador Fu Ying, who served as the spokesperson of the Parliament on foreign policy issues and currently at Tsinghua University, argued that the US is not in a superior position and has considerably weakened due to Iraq / Afghanistan wars, COVID-19 and losing competitiveness. Fu suggested that China should follow "cooperative competition" model with the new US administration $^{25}$. Yan Xuetong, a leading international relations expert at Tsinghua University suggested that uneasy peace with the US is likely to continue in the near future resulting in unpredictability and uncertainty. Yan suggested that China can make a truck with Biden's multilateral approach although it could result in the rise of political issues and friction with $\mathrm{China}^{26}$. He suggested to arriving at

=46 (accessed: 12.12.2020); U.S. and China Relations: Rising to New Global Challenges // China - United States Exchange Foundation. January 28, 2021. URL: https://www.prnewswire.co.uk/news-releases/u-s-andchina-relations-rising-to-new-global-challenges-884969 285.html (accessed: 14.02.2021).

${ }^{24}$ See: Zhou C. As Biden takes office, US still viewed as 'grey rhino' risk for Chinese economy // South China Morning Post. January 21, 2021. URL: https://www.scmp.com/economy/global-economy/article/ $3118711 /$ biden-takes-office-us-still-viewed-grey-rhinorisk-chinese (accessed: 10.02.2021); Wenling C. Where Is the US Strategy Towards China Heading for? // China Focus. July 16, 2020. URL: http:/www.cnfocus.com/ where-is-the-us-strategy-towards-china-heading-for/ (accessed: 11.02.2021).

${ }^{25} \mathrm{Fu}$ Y. Cooperative Competition Is Possible Between China and the U.S // The New York Times. November 24, 2020. URL: https://www.nytimes.com/2020/11/24/ opinion/china-us-biden.html?searchResultPosition=1 (accessed: 14.12.2020).

${ }^{26}$ Liu Z. China must stop 'wishful thinking' that rivalry with US will end with Biden // South China Morning Post. consensus with the US on competition but through humane authority and moral realism. Wang Jisi and Jin Canrong, belonging to the "strategic ambiguity" school and influential in policy circles, argued for the bottom-line approach with the US on core issues such as Taiwan and South China Sea. Yang Jiamian of Shanghai Institute of International Studies decried the US full-fledged attacks on China in the recent past and stated that these affected the dignity and core interests of China [Yang 2020]. Shi Yinhong of the People's University suggested that as the conflict scenarios had risen between China and the US, China needs to scale down and follow "strategic and military retrenchment" in order to reduce tensions with the $\mathrm{US}^{27}$. Wu Xinbo, heading the American Studies department at Fudan University in Shanghai, stated that competition with the US is normal in the economic and technological fields but not in ideological domain [Wu, Green 2014]. $\mathrm{He}$ alerted to the emergence of multitude of conflict points with the US and suggested to COVID-19 related cooperation.

\section{Conclusions}

The above brief overview of the China U.S. relations in the recent period highlighted the challenges that beset the two large economies in the world. A new Administration in the US is unfolding its policies towards China that have become frostier in the last more than a year. There are structural problems that beset these relations at trade, political, diplomatic and strategic levels. While it is hard to predict any bilateral relations, given the widespread differences between the two it is safe to suggest that U.S. - China relations continue to exhibit a complex web of ties in the coming period that are likely to impact on the regional and global affairs. Much of the engagement consensus

December 3, 2020. URL: https://www.scmp.com/news/ china/diplomacy/article/3112336/china-must-stop-wishfulthinking-rivalry-us-will-end-biden (accessed: 04.01.2021).

27 Hass R. How China is responding to escalating strategic competition with the US // Brookings. March 1, 2021. URL: https://www.brookings.edu/articles/howchina-is-responding-to-escalating-strategic-competitionwith-the-us/ (accessed: 01.03.2021). 
between the two is broken while a new modus vivendi is yet to take shape suggesting to the precariousness of the bilateral relations. China would prefer the old set of "cooperation and competition" so as to gradually rise in the regional and global orders, while for the US it is exploring on how to maintain its pre-eminence position at a time it is hit hardly by the
COVID-19 pandemic and economic and technological challenges. China's advances on the RCEP and investment deal with the European Union further constrained the US role. This situation then is likely to provide both opportunities and challenges for other countries in the international system.

Received / Поступила в редакцию: 01.03.2021 Accepted / Принята к публикации: 02.04.2021

\section{References / Библиографический список}

Allison, G. (2017). Destined for war: Can America and China escape Thucydides's trap? Boston: Houghton Mifflin Harcourt.

Anonymous. (2021). The Longer Telegram: Toward A New American China Strategy. The Atlantic Council. Retrieved from https:/www.atlanticcouncil.org/wp-content/uploads/2021/01/The-Longer-Telegram-TowardA-New-American-China-Strategy.pdf

Askari, M.U., \& Tahir, M. (2020). Sino-US rivalry in the South China Sea: A hegemonic stability theory perspective. Journal of Politics and International Studies, 6(2), 115-127. Retrieved from http://pu.edu.pk/ images/journal/politicsAndInternational/PDF/8_v6_2_2020.pdf

Boylan, B.M., McBeath, J., \& Wang, B. (2021). US - China relations: Nationalism, the trade war, and COVID-19. Fudan Journal of the Humanities and Social Sciences, 14(1), 23-40. https://doi.org/10.1007/s40647-02000302-6

Chi, M., \& Qiao, L. (2020). A skeletal review of the Sino-US "trade war": Contentious issues, trade multilateralism and policy recommendations. Canadian Foreign Policy Journal, 26(1), 99-107. https://doi.org/10.1080/ 11926422.2019.1685557

Fels, E. (2016). Shifting power in Asia-Pacific? The rise of China, Sino-US competition and regional middle power allegiance. Switzerland: Springer. https://doi.org/10.1007/978-3-319-45689-8

Gopal, P. (2017). Maritime security in the Indo-Pacific: The role of the US and its allies. Maritime Affairs: Journal of the National Maritime Foundation of India, 13(1), 27-40. https://doi.org/10.1080/09733159.2017.1321208

Kubo, F. (2019). Reading the Trump administration's China policy. Asia-Pacific Review, 26(1), 58-76. https://doi.org/10.1080/13439006.2019.1633153

Lampton, D.M. (2013). A new type of major-power relationship: Seeking a durable foundation for US - China ties. Asia Policy, (16), 51-68.

Liu, X. (2021). Chinese multinational enterprises operating in Western Economies: Huawei in the US and the UK. Journal of Contemporary China, 30(129), 1—42. https://doi.org/10.1080/10670564.2020.1827351

Lysne, O. (2018). The Huawei and Snowden questions: Can electronic equipment from untrusted vendors be verified? Can an untrusted vendor build trust into electronic equipment? Switzerland: Springer. https://doi.org/10.1007/978-3-319-74950-1

Odgaard, L. (2007). The balance of power in Asia-Pacific security: US - China policies on regional order. The Korean Journal of Defense Analysis, 19(1), 29 - 46. https://doi.org/10.1080/10163270709464126

Oliveira, A.C.G.D. (2021). From panda to dragon: An analysis of China's maritime actions and reactions in the East China Sea and their implications since 2012. Contexto Internacional, 43(1), 147-171. https://doi.org/10.1590/ s0102-8529.2019430100007

Qiu, L.D., \& Wei, X. (2019). China - US trade: Implications on conflicts. China Economic Journal, 12(2), 175-194. https://doi.org/10.1080/17538963.2019.1598014

Rosen, D.H., \& Hanemann, T. (2014). The changing US - China investment relationship. China Economic Journal, 7(1), 84-102. https://doi.org/10.1080/17538963.2013.874071

Sargent, D.J. (2014). A superpower transformed: The remaking of American foreign relations in the 1970s. Oxford: Oxford University Press.

Sutter, R. (2020). China's relations with the United States. In D. Shambaugh (Eds.), China and the world (pp. 211-232). Oxford: Oxford University Press.

Swaine, M.D. (2018). Chinese views of foreign policy in the 19th party congress. China Leadership Monitor, 55(23), 1-13. Retrieved from https://carnegieendowment.org/files/clm55-ms-final.pdf 
Tao, W. (2015). A brief history of China - US relations, 1784-2013. Beijing: Foreign Languages Press.

Wang, D. (2010). China's trade relations with the United States in perspective. Journal of Current Chinese Affairs, 39(3), 165-210. https://doi.org/10.1177/186810261003900307

Wu, X. \& Green, M. (2014). Regional security roles and challenges. In N. Hachigian (Eds.), Debating China. The U.S. - China relationship in ten conversations (pp. 198-220). Oxford: Oxford University Press.

Yang, J. (2020). Major power relations in a post-pandemic world order. China Quarterly of International Strategic Studies, 6(1), 1-18. https://doi.org/10.1142/S2377740020500074

Yang, X. (2021). US - China crossroads ahead: Perils and opportunities for Biden. The Washington Quarterly, 44(1), 129-153. https://doi.org/10.1080/0163660X.2021.1894723

Ye, X. (2020). Explaining China's hedging to the United States' Indo-Pacific strategy. China Review, 20(3), $205-238$.

Yetiv, S.A. \& Oskarsson, K. (2018). Challenged hegemony: The United States, China, and Russia in the Persian Gulf. Stanford: Stanford University Press.

Zuo, X. (2021). The Trump effect: China's new thoughts on the United States. The Washington Quarterly, 44(1), 107-127. https://doi.org/10.1080/0163660X.2021.1893515

\begin{abstract}
About the author: Kondapalli Srikanth - PhD, Professor in Chinese Studies, Centre for East Asian Studies, School of International Studies, Jawaharlal Nehru University, New Delhi, India; ORCID: 0000-0002-9559-8492; e-mail: profsrikanthkondapalli@gmail.com
\end{abstract}

Сведения об авторе: Кондапалли Шрикант - PhD, профессор Центра восточноазиатских исследований, Школа международных исследований Университета Джавахарлала Неру, Нью-Дели, Индия; ORCID: 0000-0002-9559-8492; e-mail: profsrikanthkondapalli@gmail.com 